\title{
Lumen
}

Selected Proceedings from the Canadian Society for Eighteenth-Century Studies

\section{'Preternatural Pollutions': Nature, Culture, and Same-Sex Desire in Edward Ward's 'Of the Mollies Club'}

\section{Lauren Craig Stephen}

Volume 24, 2005

Indigenes and Exoticism

Indigènes et exotisme

URI : https://id.erudit.org/iderudit/1012178ar

DOI : https://doi.org/10.7202/1012178ar

Aller au sommaire du numéro

Éditeur(s)

Canadian Society for Eighteenth-Century Studies / Société canadienne d'étude du dix-huitième siècle

ISSN

1209-3696 (imprimé)

1927-8284 (numérique)

Découvrir la revue

Citer cet article

Stephen, L. C. (2005). 'Preternatural Pollutions': Nature, Culture, and Same-Sex Desire in Edward Ward's 'Of the Mollies Club'. Lumen, 24, 105-120.

https://doi.org/10.7202/1012178ar

Copyright (C Canadian Society for Eighteenth-Century Studies / Sociéte canadienne d'étude du dix-huitième siècle, 2005
Ce document est protégé par la loi sur le droit d'auteur. L'utilisation des services d'Érudit (y compris la reproduction) est assujettie à sa politique d'utilisation que vous pouvez consulter en ligne.

https://apropos.erudit.org/fr/usagers/politique-dutilisation/ 


\section{8. 'Preternatural Pollutions': Nature, Culture, and Same-Sex Desire in Edward Ward's 'Of the Mollies Club'}

Condemnations of sodomy in the eighteenth century often attack desire between men as both unnatural and uncivilized, despite the supposed binary opposition of nature and culture. Sodomy is depicted as a crime against nature at the same time as it is a 'beastly' act - the way an animal would behave. As Cameron McFarlane points out in his study of representations of sodomy in the period, within the logic of the nature/culture binary

to become 'civilized' should mean to become 'unnatural'; to become 'uncivilized' implies a lapsing into the state of 'nature.' Yet nature and culture do not exist in anything like a stable relationship to each other.... Representations of the sodomite draw upon [multiple] models of the nature/culture binary, often simultaneously. ${ }^{1}$

McFarlane is not primarily interested in conceptions of nature and culture, but his discussion raises some important questions: for example, exactly what assumptions about nature and culture can lead to a belief that male same-sex desire violates the 'laws' of both? And what is the logic of a text that simultaneously uses apparently contradictory models of nature and culture to condemn male same-sex desire?

In his description 'Of the Mollies Club' in The Secret History of Clubs (1709), Edward Ward (1667-1731) writes of how the mollies - an early-modern term for effeminate men who desired other men - 'turn their Juvenile Desires towards preternatural Pollutions. ${ }^{2}$ The phrase is typically ambiguous about the position of same-sex desire in relation

1 Cameron McFarlane, The Sodomite in Fiction and Satire, 1660-1750 (New York: Columbia University Press, 1998), 39.

2 Edward Ward, The Secret History of Clubs (London, 1709), 288. 
to nature. Does Ward's use of the prefix 'preter' - from the Latin praeter which can mean 'beyond,' 'above,' or 'besides' (OED) - mean that the mollies are above nature or outside of it? Is Ward suggesting they are supernatural? That Ward calls their desires 'juvenile' seems at odds with his claim of their preternaturalness, since characterizing the mollies as infantile or immature would appear to place them within, not without, a model of man's 'natural' development, albeit at an arrested stage. One could argue that being juvenile made a person more natural; after all, simple or child-like people were often referred to as 'naturals.' All of which may cause us to ask: is an improving culture the correction for the mollies' juvenile desires or is a corrupting culture the source of their pollutions of nature? What exactly does Ward believe is polluting about same-sex desire and what does it pollute? Through examining Ward's text, this essay explores the place(s) of male homoerotic desire within (and without) the perceived natural order of the eighteenth century.

Many of the most pressing concerns of queer studies involve questions of nature and culture. The ongoing cultural debate about the extent to which homosexuality is an essential or socially constructed trait is, of course, a debate about which of nature or culture is responsible for it. The work of Michel Foucault perhaps has had the greatest impact on academic considerations of such questions (at least in the humanities). In his History of Sexuality Foucault rejects the familiar notion that a natural, internal sexuality is repressed by powerful modern social (scientific, medical, judicial) institutions and discourses. Sexual identities are rather an effect of social forces. ${ }^{3}$ Strongly informed by Foucault, Alan Bray's Homosexuality in Renaissance Europe, with its proclaimed goal of seeing the past 'in its own terms' and 'grasp[ing] where homosexuality was placed in the mental universe of the people who lived in that long past society' is an influential example of a social constructionist argument. ${ }^{4}$ Bray's final chapter, 'The Molly,' traces the emergence of an urban homosexual subculture - and, Bray believes, an emerging homosexual identity - in the late seventeenth and early eighteenth centuries, including gay clubs or 'molly houses.' Bray contends the term molly 'differs profoundly' from earlier terms such as 'bugger' or 'sodomite,' in that it referred to homosexuality alone rather than a general sort of sexual

3 Michel Foucault, 'The Repressive Hypothesis' in The History of Sexuality, Volume 1: An Introduction (1976), trans. Robert Hurley (New York: Vintage Books, 1978), 15-36.

4 Alan Bray, Homosexuality in Renaissance England (London: Gay Men's Press, 1982), 10. 
perversion; for this reason he sees the term as an early forerunner of the later homosexual. ${ }^{5}$ Like Bray, cultural historians Rictor Norton and Randolph Trumbach see eighteenth-century popular representations of mollies such as Ward's text as 'evidence' of an emerging gay identity. ${ }^{6}$ And yet, as McFarlane reminds us, we must keep in mind that such texts are representations, and virtually all of them overwhelmingly hostile ones; we have no transparent access to the lived experiences of men who desired other men in the eighteenth century and need to be extremely wary of speculation regarding how such men might have understood the relationship between their desire and their social identity. ${ }^{7}$ Rather than attempting such speculation, this paper argues instead that the contradictions of representing sodomy as both unnatural and uncivilized create an awareness / fear in Ward's text that nature is not an unchanging absolute, but is in fact a matter of custom and convention and, therefore, subject to change and reinvention.

Edward (Ned) Ward was a popular and prolific writer whose subject matter was the everyday and often seamy side of London life. His writing style tends towards the hyperbolic, and he 'was best known for the violent political views he loved to express. ${ }^{8}$ Expressing such views occasionally landed Ward in trouble with the authorities: at one point he was sentenced to stand in the pillory for a bitter attack on the Whigs. ${ }^{9}$ The opinion that Ward was a mediocre-at-best talent seems to have been shared both by his contemporaries and by more recent commentators: he is one of the targets of the first book of Pope's The Dunciad (1728); and the only published book-length study of Ward, Howard Troyer's Ned Ward of Grub Street, opens with the warning that the author has 'no apology to offer for Ned Ward. ${ }^{10}$ On the other hand,

5 Bray, 103.

6 Rictor Norton, Mother Clap's Molly House: The Gay Subculture in England, 1700-1830 (London: Gay Men's Press, 1992). Randolph Trumbach, 'Sodomy Transformed: Aristocratic Libertinage, Public Reputation, and the Gender Revolution of the Eighteenth Century,' Journal of Homosexuality 19, no. 2 (1990): 105-24.

7 McFarlane, 19.

8 Arthur L. Hayward, 'Foreword' to Edward Ward, The London Spy: The Vanities and Vices of the Town Exposed to View (1698-1700), ed. Arthur L. Hayward (Toronto: Cassell, 1927), ix.

9 In Hudibras Redivivus: Or, A Burlesque Poem On The Times (London, 1705).

10 Howard William Troyer, Ned Ward of Grubstreet: A Study of Sub-Literary London in the Eighteenth Century (Cambridge: Harvard University Press, 1946), vii. 
as part of an early generation of freelance pamphleteers and journalists, Ward proved remarkably successful in gauging popular tastes and adapting his writing style and subject matter to meet the demands of the marketplace, and indeed in innovating to stimulate new demands. A Trip to Jamaica (1698) capitalized on the popularity of travel writing and tales from the English colonies, but with an attention to the daily life and environment of colonists rarely before seen. ${ }^{11}$ It was this focus on ordinary life that was key to the popularity of The London Spy (1698-1700), in which Ward adopted the persona of a country scholar led around town by his worldlier schoolfellow. As a 'spy' into London life, Ward is explicitly voyeuristic in his goal of 'expos[ing] the vanities and vices of the town ... so that the innocent might see by reflection what I should gain by observation and intelligence, and not by practice or experience. ${ }^{12}$ This device allows Ward to depict the sordid details of London life - prostitution, sodomy, public whippings - while ostensibly remaining separate from and superior to them. It is a stance he adopts again in The Secret History of Clubs, particularly in the 'Mollies Club' chapter, where he condemns sodomy as unnatural and uncivilized while lingering on the salacious details of the mollies' behaviour.

A difficulty Ward struggles with in 'Of The Mollies Club' is how to represent what is supposed to remain unrepresented, the sin that he claims 'ought for ever to be without a name. ${ }^{13}$ Sodomy was so intolerable that it was scandalous even to speak or write about it. Several scholars have suggested why this might be, arguing that the primary transgression of sodomy is that it confounds meaning and signification: for Foucault sodomy is 'that utterly confused category,' for Bray it 'existed as a potential for confusion and disorder,' and for McFarlane sodomy 'signifies confusion by confusing signification. ${ }^{14}$ If sodomy was a confusion of signification, then in order for early modern writers to represent it, even in the form of a condemnation, they risked reproducing the transgression that they sought to suppress. This, perhaps, is the reason sodomy was supposed to remain unmentioned.

11 Edward Ward, A Trip To Jamaica: With a True Character Of The People and Island (London, 1698).

12 London Spy, 2.

13 Secret History, 284.

14 Foucault, 101; Bray, 25; McFarlane, 26. 
One challenge to signification that the sodomitical and cross-dressing mollies present to Ward is that the signifier of the human male body fails to signify what it 'should,' manliness, and instead signifies its 'opposites': effeminacy, bestiality, monstrosity, and 'devilism.' And yet by showing what he believes should not be, men acting like women, Ward must acknowledge that what should not be can be, that sex and those traits and behaviours linked to sex (what we today call gender) are not necessarily a unity. Similarly, by showing humans acting 'against their nature' as if they were monsters, beasts, or devils, Ward undermines the concept of human nature he tries to present as universal. Although the mollies' crime is an improper use of their male bodies, Ward interestingly makes few direct references to those bodies, referring to sodomy euphemistically as 'odious bestialities,' 'preternatural pollutions,' 'unmanly liberties,' and 'the backward way. ${ }^{15}$ This may be a strategy to condemn sodomy without actually breaking the taboo of naming it. However, it also has to do with Ward's multi-pronged attack: the mollies must anatomically be men in order for Ward to emphasize the artificiality of their performance of femininity, but he keeps that anatomy vague so that he may accuse them of being not quite human, 'two leg'd brute[s]' who act 'as if no woman was their mother.'16

In attempting to define the natural and the other-than-natural, early modern arguments about same-sex desire make repeated references to such categories as 'man,' 'woman,' 'beast,' 'brute,' and 'monster,' terms already invested with powerful assumptions about their relations to nature and culture. In their article 'The Hermaphrodite and the Orders of Nature,' Lorrain Daston and Katherine Park argue that the polarity of nature versus culture would not have made as much sense to early moderns as it does to us today. Instead, they argue, early moderns considered the social status of hermaphrodites 'in terms of the dichotomies that were meaningful to them: natural versus artificial, natural versus preternatural, and natural versus unnatural':

The artificial encompassed all that was made by human industry; according to Aristotle, the artifact lacks a true 'nature' - that is, 'the distinctive form or quality of such things as have within themselves a principle of motion....' Preternatural phenomena were rare and unusual, outside the ordinary course of nature, but in principle fully explicable by natural causes.... Finally, unnatural 
acts transgressed the moral dictates laid down by what Aquinas called the 'author of Nature'; stock examples included a mother murdering her children... or bestiality. ${ }^{17}$

In each of these cases, nature was generally the normative, although the artificial and unnatural were more often negative while the preternatural had something of the marvellous about it. In light of this, Ward's characterization of the mollies as 'preternatural' seems somewhat unusual since the term 'unnatural' would have most clearly established their opposition to nature.

In Wonders and the Orders of Nature, Daston and Park contend that it was wonders of nature that occupied the realm of the preternatural, 'suspended between the mundane and the miraculous. ${ }^{18}$ Significantly, Daston and Park do not agree whether wonders and preternatural phenomena contradict and destabilize the order of nature or round it out. We may similarly ask whether the mollies, whose sodomy and effeminacy appear to confound and contradict the natural/sexual order Ward seeks, are truly transgressive or whether their transgressions serve further to enforce that natural order. There is much in Ward's Secret History that suggests marvel and wonder. The dedicatory epistle is facetiously addressed to 'The Emperor of the Moon': because, Ward writes, 'I have principally treated of the Madness of Mankind in the following sheets so I thought the Lunacies of this world a proper subject to entertain your Highness. ${ }^{19}$ Later in the preface Ward refers to his subject matter as 'those Whimsical Clubs. ${ }^{20}$ Such gestures - and the term 'preternatural' - complicate the text's moralizing by suggesting the mollies are intended to provoke wonder and amusement, not only horror and outrage.

On the other hand, it is difficult to ignore the sheer hostility of Ward's attack. And the dichotomy of natural-preternatural is not the only one Ward deploys in this text. From the beginning of his depiction, Ward also emphasises the artificiality of the mollies. The mollies

17 Lorrain Daston and Katherine Park, 'The Hermaphrodite and the Orders of Nature: Sexual Ambiguity in Early-Modern France,' GLQ: A Journal of Lesbian and Gay Studies 1, no. 4 (1995): 425-28.

18 Lorrain Daston and Katherine Park, Wonders and the Orders of Nature (New York: Zone Books, 2001), 14.

19 Secret History, no pagination.

20 Ibid., 6. 
are so far degenerated from all masculine Deportment, or manly Exercises that they rather fancy themselves Women, imitating all the little Vanities that custom has reconcil'd to the Female Sex, affecting to Speak, Walk, Tattle, Cursy ${ }^{21}$, Cry, Scold, and to mimick all Manner of Effeminacy, that ever has fallen within their several observations; not omitting the Indecencies of lewd Women, that they may tempt one another by such immodest Freedoms to commit those odious Bestialities, that ought for ever to be without a Name. ${ }^{22}$

Ward's choice of words here - fancy, imitate, affect, mimic - emphasize that this is a false (and clearly inferior) form of femininity. It is not simply the transgression of gender boundaries that bothers Ward, but he makes it clear that this is a 'degeneration' from 'masculine Deportment' and 'manly Exercises' into a degraded stereotypical femininity: crying, gossiping, tattling, scolding. Ward oscillates, though, between condemning the mollies' version of femininity and defending the honour of good English women against the mollies who 'Scoff' at women and would 'both sexes...disgrace. ${ }^{.23}$ In his concluding poem he writes:

Our Ladies are so Kind and Fair,

So Gay, and Lovely, to the Sight,

So full of Beauty and Delight. ${ }^{24}$

The mollies, significantly, do not mimic the women who are 'kind and fair,' but instead behave like women of the 'worst' sort: gossips and 'lewd women' who have 'laid aside their modesty for the delights of the bottle. ${ }^{25}$ The mollies, then, are inferior women both because they are artificial ones and because they mimic the worst stereotypically feminine traits.

The emphasis on the idea that the mollies are artificial, rather than natural, women suggests that there is little in their natures that makes them effeminate, or attracted to their own sex. Indeed, they appear to have an ingrained heterosexual attraction, since they must imitate 'lewd Women, that they may tempt one another' - the mollies do not desire each other as men, but rather (performing) as women. Their same-sex

21 I.e. curtsy - but with the suggestion of cursing?

22 Secret History, 284.

23 Ibid., 288, 299.

24 Ibid., 298-99.

25 Ibid., 285. 
attraction strangely operates as a form of heterosexuality here. We later learn, though, that before turning to their 'preternatural pollutions' the mollies cast off their feminine airs and 'make a Scoff and a little Banter of the little Effeminate Weaknesses which Women are subject to...on purpose to extinguish that Natural Affection which is due to the fair sex. ${ }^{26}$ At this point their desire appears rooted in misogyny, a misogyny that must be deliberately worked at through cross-dressing and mockery in order to overcome their natural inclination towards heterosexuality. These two passages are certainly contradictory: Ward attacks the mollies for scoffing at 'the fair sex,' despite his own derision of the 'Vanities' of the 'Female Sex'; and if they act like women in order to tempt one another, why must they then 'extinguish that Natural Affection' for women? This also raises the question of motivation: why would the mollies want to go to so much trouble in order to arouse a desire that goes so against their natures? In this sense Ward is working against himself - the more unpleasant and unnatural he makes sodomy seem, the less credible his depiction of the mollies becomes. In any event, both these passages argue that the mollies are stubbornly heterosexual by their nature, so much so that they must enact these elaborate rituals in order to bypass that nature.

Because the mollies are essentially or instinctively heterosexual, their 'pollution' seems to be that of their own human nature (or perhaps more precisely, male nature). They 'turn' their desires towards preternatural pollutions not only in the relatively neutral sense of changing their focus of attention, but also in the graver sense of bending or perverting their desires away from their natural direction. This turning away from human nature sinks the mollies into a filthy animal nature; hence they commit 'odious bestialities,' 'beastly obscenities,' and 'beastly practice[s],' and are labelled 'swine,' 'brutes,' and 'Ape[s]. ${ }^{.27}$ Words such as 'beastly' and 'brutal,' though, are usually used to describe those whose 'animal' passions or drives have overcome their reason, which would seem to contradict the fact that the mollies must consciously extinguish their natural passions. Ward could, of course, simply mean that the mollies' behaviour resembles that of animals, which may be acceptable for animals but not for humans. His concluding poem begins to suggest this, but quickly slides into an antithetical view of the relationship between 
animal and human natures. According to Ward, while swine may 'wallow belly deep in muck':

...Men who chuse this backward Way, Are fifty Times worse Swine than they:

For the less Savage four-leg'd Creature,

Lives but according to his Nature:

But the Bug'ranto two leg'd Brute,

Persues his Lust contrary to't;

The brawny Boar will love his Sow;

The Horse his Mare; the Bull his Cow;

But Sodomites their Wives forsake,

Unmanly Liberties to take. ${ }^{28}$

That the mollies are 'worse' than swine reveals 'animal' to be an already devalued category, like 'woman.' What is especially interesting about this passage, though, is that Ward believes it goes against human nature to imitate an animal by wallowing in muck, but at the same time this passage holds up (his belief in) animals' exclusive heterosexuality as an example to follow. Humans are 'swine' if they follow the swine's example of wallowing in dirt, but are beastly if they do not follow its example of heterosexuality. If it is 'unnatural' for humans to behave like animals in some ways, but 'natural' in others, how are we to know which examples to follow and which to reject?

Ward condemns the mollies not only because they do not act like 'men,' but also because he believes the categories that they imitate, 'woman' and 'beast,' are inferior to 'man.' The 'Female Sex' is mostly degraded to the familiar stereotypes of tattling gossips, and Ward emphasises the 'Effeminate Weaknesses which Women are subject to' ${ }^{29}$; they are also 'subject to' 'impertinent Tittle Tattle... when they have laid aside their Modesty for the Delights of the Bottle. ${ }^{30}$ The fact that women are 'subject to' these 'weaknesses' suggests a lack of control or mastery over themselves, mastery which men presumably should have. The mollies are 'wretches,' in Ward's opinion, because they have given up that mastery over self. An interesting aspect of Ward's attack, though, is that he ridicules women because he claims they are subject to weaknesses

29 Ibid., 288.

30 Ibid., 285. 
that seem in their nature, implying that it would be better if they could overcome that nature, yet the mollies are condemned because their behaviour violates their masculine nature. 'The Mollies Club' suggests, then, that there is a human nature that should be followed and one that should not be.

In her book What is Nature? Kate Soper notes that what is believed to be proper to human nature is determined 'both in approval and rejection' of the 'custom of nature,' by what is thought to be spontaneous and instinctual. Human nature is thus closely related to animal nature, but with a significant difference: while animals are generally presumed to act always according to their nature - and thus animal nature is essentially a description of how animals behave - human nature is a combination of the descriptive and the prescriptive. For this reason, Soper contends that, while we may claim certain behaviours follow or betray our 'human nature,' such statements in fact subvert concepts of human nature since they must allow that humans are capable of defying their 'nature' in ways denied to other animals. She writes: 'It is to suggest, in effect, that "human nature" is such as to be realized only in compliance with a certain order of "conventions" of a kind that no other creature can be expected to recognize or would require its fellows to observe. ${ }^{\prime 31}$ This is one way in which early-modern condemnations of sodomy repeat the transgression they seek to suppress, since any prescriptive view of human nature, such as the one Ward posits, must acknowledge that nature is not followed by everyone, nor is it apparent to everyone. The objective for Ward is to determine human nature so that he may prescribe certain types of human behaviour. For this determination he cannot simply describe how humans behave and call that their 'nature,' since this would make all human behaviour 'natural.' And humans clearly are not supposed to act like animals in every way. For his argument based on animal behaviour to succeed, he and the reader must already ' $\mathrm{know}^{\prime}$ what proper human nature is. Ward paradoxically claims a universal nature, which is not universally followed. 'Sodomites' act, 
As if no Woman was their Mother:

For he that is of Woman born,

Will to her Arms again return. ${ }^{32}$

And yet the existence of the mollies demonstrates that he that is of woman born will not inevitably return to her arms. The method of Ward's argument has shifted from saying that humans should follow the example of animal behaviour to saying that humans should follow the example of human behaviour; in other words, all humans should behave a certain way because all humans behave that way a completely tautological statement.

Daston and Park suggest that in the early-modern period what was considered natural 'was a blending of the descriptive and the normative':

On one hand, the natural described what happened always or mostly-nature's custom. On the other hand, nature prescribed what should happen, because a teleological principle required that outcome, either because such ends were built into nature or because nature executed God's will. ${ }^{33}$

A central teleological principal implicit in Ward's statement is that of reproduction. Nature and/or God require man to propagate the species, and so man must necessarily and inevitably return to woman. That the mollies exist outside this inevitable 'natural' cycle further marks them as something that simply should not be. By polluting their human nature, they cease to be quite human, and part of Ward's project is to present the mollies as rhetorically inhuman, 'Brutes that pass for Men.' Since they are not 'of woman born,' at least figuratively, Ward speculates on their origins:

Sure the curs'd Father of this Race,

That does both Sexes thus disgrace, Must be a Monster, Mad, or Drunk, Who, bedding some preposterous Punk,

Mistook the downy Seat of Love,

And got them in the Sink above; 
So that, at first, a Td [Turd $]^{34}$ and They

Were born the very self same way. ${ }^{35}$

Instead of having mothers, the mollies are the excrement of 'some preposterous Punk.' Ward sees their creation and existence, then, as an affront to 'proper' or 'natural' procreation. This 'mythological' father of sodomy 'mistakes' the 'Seat of Love' not only because he is confused or fails to recognize it, but also mis/takes it: he does not correctly 'take' it in the sexual sense; indeed he misses taking the 'proper' seat of love altogether.

The mollies disgrace procreation in another way, through the bizarre mock birth that they enact. On 'one of their Festival Nights':

...they had cusheon'd up the Belly of one of their Sodomitical Brethren, or rather Sisters, as they commonly call'd themselves, disguising him in a Womans Night-Gown, Sarsnet-Hood, and Nightrale, who, when the Company were met, was to mimick the wry Faces of a groaning Woman, to be delivered of a joynted Babie they had provided for that Purpose, and to undergo all the Formalities of a Lying in. The Wooden Off-spring to be afterwards Christen'd, and the holy Sacrament of Baptism to be impudently Prophan'd, for the Diversion of the Profligates. ${ }^{36}$

34 On his website, Homosexuality in Eighteenth-Century England: A Sourcebook (http://www.infopt.demon.co.uk/nedward.htm), Rictor Norton offers 'toad' instead of 'turd' here, noting that toads were believed to be born 'from the anus according to folklore.' However it seems unlikely that Ward would have feared using the word turd, even in this context. After all, he seems to have had no trouble being gratuitously scatological at other times - in the preface to the Secret History of Clubs he comments on having his works 'read and commended within my own Hearing': 'I can compare it to nothing, but, that Necessity having forc'd me to Dung another Man's Ground, and the Owner, because he's pleased with the freedom I have taken, should thrust my Nose into my own Puddings'(3). Turd would have been the more vulgar term and the one to elide: the Oxford English Dictionary entry on 'Turd' quotes T. Brown from 1704, 'Out you nasty td colour'd dog.' The fact that Ward's 'td' is born might suggest a living creature, but we can certainly read born in the more general sense of being generated or created. Of course, ' $\mathrm{td}$ ' may certainly be a deliberate play on the ambiguity of toad/turd, in which case it is another example of sodomy being associated with a degraded, dirty animality.

35 Secret History, 299-300.

36 Ibid., 285. 
McFarlane notes that this is a 'gleeful mocking' of procreation, 'the very practice [the mollies] are in the process of frustrating' through their sodomy, and he believes Ward is stressing 'the desecration of social and religious practices that is taking place.' This near-occult ritual, McFarlane argues, 'recalls the earlier construction of the sodomites as devilish creatures, suggesting that they are almost like a coven, performing perverted versions of sacred rituals. ${ }^{, 37}$ The 'earlier construction' McFarlane refers to here is the Renaissance conception of the sodomite. In Renaissance England the term sodomy was used to describe a wide range of sexual transgressions committed by men or women. It could refer to homosexual behaviour, bestiality, incest, adultery, non-procreative sex, and even celibacy (because of its association with Roman Catholicism and because it prevents procreation). Alan Bray notes that sodomy was often linked with atheism, heresy, Catholicism, and treason. The sodomite was a demonic figure, referred to in the same breath as wizards and werewolves. As the seventeenth century progressed, sodomy came increasingly to refer to sex between men and lost most of its supernatural associations. It seems likely, however, that Ward, writing in the early eighteenth century, would be aware of these earlier associations; the sacrilegious mock-birth and use of 'preternatural' seem to suggest this. Because of its supernatural associations, Bray contends, in the 'symbolic universe' of Renaissance England sodomy 'was not part of the chain of being, or the harmony of the created world,' but rather represented its dissolution and 'a potential for confusion and disorder. ${ }^{38}$ In this way the mollies are 'preternatural' because they do not exist in the natural order in any positive sense, but only as a negative, as a mockery of that order. Although the mollies' 'pollutions' are first and foremost of their human nature, they also have implications for the larger 'natural' order, such as the 'natural' cycle of reproduction.

A.O. Lovejoy offers some insight into the relationship between human nature and the (perceived) larger natural order. Lovejoy contends that the eighteenth century saw the 'widest diffusion and acceptance' of the idea that nature was ordered into a hierarchy, or a 'Great Chain of Being'

38 Bray, 24-25. The sodomite was so antithetical to Renaissance society, Bray argues, those who felt or acted on same-sex desire likely made no connection between their behaviour and 'sodomy' (68-69). 
with God at the top, then angel, man, woman, ${ }^{39}$ animal, plant, etc. Lovejoy believes that the most significant ethical consequence in the eighteenth century of the idea of nature as a chain of being was a belief that it was 'man's duty to keep his place' in the Chain since 'every place in the scale must be filled, and since each is what it is by virtue of the special limitations which differentiate it from any other.' It therefore would be immoral for 'man' to seek to behave like any other link in the chain. Early moderns believed, in Lovejoy's words, that there must be 'a specifically human excellence which it is man's vocation to achieve. ${ }^{\prime 40}$ Thus Pope's 'Essay on Man' (1732) counsels man to understand and accept his 'middle nature' between God and beast. Even though it is a cosmological view of nature, then, the chain of being operates with an assumption of a human nature. The horror Ward expresses at the mollies' 'degenerat[ion] from all masculine Deportment,' and his reference to their 'odious Bestialities,' both speak to the idea that they are not keeping their place in the natural order, but choosing instead to behave as if they belonged to the categories of 'woman' and 'beast.' This is another reason their 'odious Bestialities...ought to be forever without a Name': they simply do not, in Ward's opinion, fit into any nameable category. In this context we can understand the mollies being 'preternatural' because they are outside their 'proper' place in the natural order; their 'pollution' of their own human nature becomes a pollution of the larger natural order.

'Of the Mollies Club' is at least as anxious about gender confusion as it is about sex between men. Most of the text is a horror-filled relation of how the mollies 'run thro' all the Ceremonies of their theatrical way of Gossiping,' and it constantly reminds the reader that this is an inferior imitation of femininity. What is unnatural about this drag performance, however, remains unclear: the mollies imitate 'all the little Vanities that Custom has reconcil'd to the Female sex'; they 'make a Scoff and a Banter of the little Effeminate Weaknesses which Women are subject to' (my

39 Lovejoy does not, in fact, mention women in his chapter entitled 'The Chain of Being in Eighteenth-Century Thought, and Man's Place and Role in Nature' (The Great Chain of Being: A Study of the History of an Idea [New York: Harper \& Row, 1960]). However, Londa Schiebinger has traced how women have historically been assigned a lower place than men in the 'natural order.' See Londa Schiebinger, 'Competing Cosmologies: Locating Sex and Gender in the Natural Order,' The Mind Has No Sex? Women in the Origins of Modern Science (Cambridge: Harvard University Press, 1989), $160-88$.

40 Lovejoy, 183-200. 
emphases). The text implies that femininity is more a matter of custom than of nature. Ward's sense of the constructed nature of gender may be a result of his own subject matter. In Gender Trouble, Judith Butler argues, 'the performance of drag plays upon the distinction between the anatomy of the performer and the gender that is being performed.' For this reason, Butler argues, drag 'reveals the distinctness of those aspects of gendered experience which are falsely naturalized as a unity through the regulatory fiction of heterosexual coherence. In imitating gender, drag implicitly reveals the imitative structure of gender itself. ${ }^{41}$ Ward has difficulty naturalizing sex and gender as a unity, because the very existence of the mollies demonstrates that such unity is not universal. Butler also argues that drag reveals gender identity - the gender with which one identifies - and gender performance as distinct from each other and from anatomical sex. At first the mollies appear to have a gender identity that is female - they 'fancy themselves women' - but they later 'scoff' at this femininity and it is revealed to be a performance. So is masculinity their 'true' gender identity or is it another 'imitation'? Are they still effeminate as men? Do we accept the mollies' denial of their femininity at face value or are we convinced with Rictor Norton that the dedication with which they perform their femininity offers 'spectacular evidence' of their female identification. ${ }^{42}$ The mollies' 'true' gender identity remains unclear. Indeed, Ward's text raises the possibility of individuals inhabiting multiple gender identities and performances simultaneously. Ward repeats the gender confusion that horrifies him so. One excellent example of this is when he laments that the mollies have 'quit the charming Petticoat.' He uses 'petticoat' as a metonym for 'woman' - suggesting a natural connection between the two - but such a metonym becomes untenable when men start wearing petticoats, as the mollies do. And since the mollies' sexual partners are other mollies, they have not, in fact, quit the petticoat.

It is the agents of the Reforming Society that finally put and end to the mollies' 'filthy scandalous Revels' by exposing and arresting them. ${ }^{43}$ Culture, then, would appear to be the corrective to those who contradict the natural order. Despite Ward's belief in the inevitability of the natural

41 Judith Butler, Gender Trouble: Feminism and the Subversion of Identity (New York: Routledge, 1990), 137.

42 Rictor Norton, Mother Clap's Molly House: The Gay Subculture in England, 1700-1830, 97.

43 Secret History, 288. 
order, nature seems to have little power to actually enforce its 'laws': the existence of the mollies demonstrates that 'he that is of Woman born' will not necessarily 'to her Arms again return.' Ward's text is so hostile to the mollies because he believes they confound accepted meanings, but his attack also participates in the 'confusion.' Ward seems to have been striving to stabilize naturalized hierarchies even as he was well aware/feared that 'Nature' was shifting as he wrote. The effect of Ward's antithetical rhetoric may well be to create a desire for the very cultural order of 'Nature' that Kate Soper identifies. If we agree with Foucault that normative social categories and identities are discursively produced, then by virtue of writing a disapproving history of this 'secret' group, Ward helped reproduce the very phenomenon he abhorred the 'exposure' of the mollies appearing to necessitate the increased social regulation of gender and sexuality. On the other hand, a dawning awareness of the cultural and historical specificity of nature - of the kind revealed in 'The Mollies Club' - must necessarily have allowed for the invention of novel 'natures' of the subject, that is, opened up new possibilities for self-fashioning based on new-fashioned natures.

\section{LAUREN CRAIG STEPHEN \\ McMaster University}

